\title{
Performance and Exhaust Gas Emission of Biodiesel Fuel with Palm Oil Based Additive in Direct Injection Compression Ignition Engine
}

\author{
C. B. How, N. M. Taib and M. R. A. Mansor* \\ Department of Mechanical Engineering, Faculty of Engineering and Built Environment, \\ Universiti Kebangsaan Malaysia, 46300 UKM Bangi, Selangor, Malaysia \\ *Email: radzi@ukm.edu.my
}

\begin{abstract}
Blending biodiesel in the diesel would increase the tendency of having a high viscosity fuel. For this reason, the addition of a small amount of additives into the blends may improve the engine performance and lead to better fuel consumption. The purpose of this paper is to experimentally investigate the performance and emissions generated by various mixtures of biodiesel and diesel with palm oil based additive in the compression ignition direct injection diesel engine of Yanmar TF90. Experiments were also conducted to identify the ideal biodiesel, diesel and the additive mixture that produces the optimum engine emission and performance. The experiment was conducted by using mixtures that consisted of $10 \%, 20 \%$ and $30 \%$ of biodiesel with and without the additives. From the results of the experiments, PB10 with $0.8 \mathrm{ml}$ additives produced the highest braking power and lowest fuel consumption as compared to the diesel and the rest of the biodiesel blends. The presence of biodiesel and additives were found to not only improve the engine performance, but also led to the reduction of carbon emission. Although all the diesel, biodiesel and additive demonstrated low smoke emission with a complete combustion, a slight increase however, was observed in the NOx emission. In conclusion, PB10 is seen as the most ideal blend for diesel engine in terms of providing the most optimum engine emission and performance.
\end{abstract}

Keywords: Biodiesel; palm oil; additives; engine performance; emission.

\section{INTRODUCTION}

The demand for transportation fuel is experiencing a rapid growth on a global scale. Presently, diesel engines are being used extensively in the automobile, generator, construction, industrial and agricultural sectors. In the automotive industry, dieselpowered vehicles are becoming very popular due to their better fuel efficiency and higher torque power when compared to those of petrol-powered vehicles. Almost one-third of the vehicles manufactured in Europe and the US are powered by diesel, while the number of diesel vehicles had shown an increase from $3.84 \%$ in 2006 to $5.11 \%$ in 2017 when compared to the previous year [1]. However, the increase has led to a growing environmental pollution as a result of the exhaust gas emission. For this reason, biodiesel is seen as not only an alternative solution to the environmental problems caused by diesel vehicles in the transportation sector, but also as an alternative energy source to reduce the dependency on petroleum sources [2], since it is derived from biological sources known as carbon neutral sources, which are renowned for producing no net carbon emissions to the surroundings [3]. 
Additionally, biodiesel fuel is a renewable energy source that shares similar properties with the diesel, hence, can be used in diesel engines without any major modifications $[3,4]$. Biodiesel can also act as a lubricant and a cetane improver that increases a diesel fuel's Cetane number, thus contributing to a better engine performance. The major source of biodiesel in Malaysia is produced from palm oil through the transesterification process. Since oil palm plantations cover about $16 \%$ of the total land area in Malaysia [3], this country has the ability to produce palm oil biodiesel with a lower fuel and energy cost [6].

It is impossible however, to directly use $100 \%$ biodiesel in diesel engines as it is highly viscous and can lead to poor fuel engine consumption. Moreover, the long term usage of $100 \%$ biodiesel in unmodified engines may lead to severe corrosion, wearing of engine parts and the high amount of carbon deposition in the combustion chamber [7], particularly during the cold weather [8]. Since most of the complications had caused by the high viscosity, density and high iodine level of the biodiesel, this has prompted many researchers to look for ways on improving the properties of biodiesel [9] such as by mixing the fuel with diesel or a fuel additive.

Various biodiesel standards have been developed and implemented worldwide to maintain and standardize the biodiesel quality. Presently, since most biodiesel fuel manufacturers adheres to the guidelines set by the US and EU standards, this research abides to the guiding principles set in the ASTM D7467 and EN 14214 biodiesel standards. The main properties of biodiesel, namely its density level, kinematic viscosity at $40^{\circ} \mathrm{C}$ and calorific value had served as the main focus of this research. As stated under the ASTM D7467 biodiesel requirements, the biodiesel density level should be less than $859 \mathrm{~kg} / \mathrm{m}^{3}$, while the kinematic viscosity at $40^{\circ} \mathrm{C}$ should be in the range of 1.9 to $4.1 \mathrm{cSt}$, since a highly viscous fuel may cause extreme pressures in the injection systems and will result in the reduced atomization and vaporization of the fuel spray [10]. As for the calorific value of diesel, the EN 14214/ D240 standard had stated the value to be around $45.6 \mathrm{MJ} / \mathrm{kg}[11]$.

All biodiesel fuels regardless of feedstock type are denser and less compressible than the diesel fuel. While density and compressibility greatly influence the engine fuel injection system [8], fuel density on the other hand, affects atomization and fuel mixture formation [12]. As such, by having a very high density and viscosity level, the biodiesel fuel has a tendency to reduce engine performance, since the high viscosity would result in a poor flow of fuel into the combustion chamber and in turn leads to a slow combustion process. However, although the complex structure with high carbon contents in the biodiesel fuel is likely to heighten the engine's incomplete combustion, it also contains a high oxygen content that can aid in the engine's complete combustion [13] and results in lesser carbon emission. While biodiesel fuel has been touted as a much cleaner alternative to conventional diesel fuel, a high NOx emission however, had been detected as a result of the higher combustion temperatures from the biodiesel's higher oxygen content.

Biodiesel fuel typically has a lower calorific value of between $39 \mathrm{MJ} / \mathrm{kg}$ to 41 $\mathrm{MJ} / \mathrm{kg}$, as compared to diesel fuel, which is between $42 \mathrm{MJ} / \mathrm{kg}$ to $45.9 \mathrm{MJ} / \mathrm{kg}$ [14] and can be measured experimentally by using a bomb calorimeter. As a result of the lower calorific value of the blended biodiesel, the braking power of the blended biodiesel would be slightly lower than the diesel fuel, hence resulting in an inefficient combustion process. Even so, some researchers had reported that a higher braking power can be achieved from blends with lower than $20 \%$ biodiesel contents due to the complete combustion and a good mixture of fuel to air ratio [15]. 
Although biodiesel fuel combustion also produces a lower brake thermal efficiency as compared to the diesel fuel due to its lower calorific value [16], the high density and its low calorific value however, would result in the escalation of its brake specific fuel consumption (BSFC). The increase in the fuel consumption is not only due to the engine burning more fuel to achieve the maximum heat at certain load but is also caused by the high density and viscosity of the biodiesel [17].

In this day and age, there is a need to control exhaust emissions such as $\mathrm{CO}, \mathrm{HC}$, $\mathrm{NO}_{x}$, soot and $\mathrm{CO}_{2}$ as these gases and pollutants contribute to serious global warming and public health issues. For this reason, biodiesel is able to produce lower levels of unburned $\mathrm{HC}, \mathrm{CO}, \mathrm{CO}_{2}$ and smoke opacity compared to diesel fuel at all engine speeds [18] because of its fuel's high viscosity [19]. Many previous studies had found the decrease of CO emissions is caused by the increasing percentage of biodiesel in the blend, but a slightly higher $\mathrm{CO}_{2}$ from the complete combustion [20] [21].This is because although the oxygen content of the biodiesel had improved the combustion cylinder, this had also led to the formation of NOx emission as a result of the high temperatures and long combustion period [22].

Given that there is a vague impression on the available additives' effectiveness on the engines as well as the ambiguous information concerning the contents of the additives in the market and the ideal mixtures of additives with the diesel, this study has therefore aimed to investigate not only the ideal biodiesel, diesel and a booster mixture in producing an optimum engine performance, but also a fuel mixture that complies with the ASTM D7467 standard. The exhaust gas emissions produced by diesel engines is also examined in this study.

\section{METHODOLOGY}

\section{Materials and Method of Blend Preparation}

The research had used a commercial fuel from public fuel stations and palm oil methyl ester that was sourced from a local supplier. The preparation of the biodiesel and additive blends was carried out at room temperature. The mixture was placed in a glass beaker before being agitated at 1000 RPM for 15 minutes. It was then left to rest for 15 minutes to reach an equilibrium state before being subjected to further testing. The biodiesel, diesel and additive mixtures were labelled accordingly as shown in Table 1.

\section{Measurement of Fuel Properties}

All of the fuel blends were tested according to the biodiesel requirements set in the ASTM D6751 and the European Union (EN 14214) standards and were subjected to the analysis of density, kinematic viscosity and calorific value properties. According to the ASTM D6751 standard, the biodiesel density should be less than $859 \mathrm{~kg} / \mathrm{m}^{3}$, while the kinematic viscosity should be below $4.1 \mathrm{cSt}$. While the density test was conducted using the relation of mass and volume of fuel, the viscosity test was conducted through the use of a Kittiwake On-board Viscometer by measuring the time taken for a stainless-steel ball to travel along the tube that was filled with the fuel. Each of the density and viscosity measurement were conducted three times. As there is no mention of the calorific value of the blended fuel in the ASTM D6751 standard for biodiesel, the calorific value of the EN 14214 standard for biodiesel was referred to instead through the use of an IKA C200 
Bomb Calorimeter. According to the requirement set in the standard, the minimum calorific value for a blended fuel should be at least $35 \mathrm{MJ} / \mathrm{kg}$.

Table 1. Biodiesel, diesel and additive blend percentages.

\begin{tabular}{|c|c|c|}
\hline No. & Blend percentage & Acronyms \\
\hline 1 & Diesel + Additive $0.8 \mathrm{ml}$ & Diesel Additive $0.8 \mathrm{ml}$ \\
\hline 2 & Diesel + Additive $2.0 \mathrm{ml}$ & Diesel Additive $2.0 \mathrm{ml}$ \\
\hline 3 & Palm biodiesel 10\% + Diesel $90 \%$ & PB10 \\
\hline 4 & $\begin{array}{l}\text { Palm biodiesel } 10 \%+\text { Diesel } 90 \%+ \\
\text { Additive } 0.8 \mathrm{ml}\end{array}$ & PB10 Additive $0.8 \mathrm{ml}$ \\
\hline 5 & $\begin{array}{l}\text { Palm biodiesel } 10 \%+\text { Diesel } 90 \%+ \\
\text { Additive } 2.0 \mathrm{ml}\end{array}$ & PB10 Additive $2.0 \mathrm{ml}$ \\
\hline 6 & Palm biodiesel 20\% + Diesel $80 \%$ & PB20 \\
\hline 7 & $\begin{array}{l}\text { Palm biodiesel } 20 \%+\text { Diesel } 80 \%+ \\
\text { Additive } 0.8 \mathrm{ml}\end{array}$ & PB20 Additive $0.8 \mathrm{ml}$ \\
\hline 8 & $\begin{array}{l}\text { Palm biodiesel } 20 \%+\text { Diesel } 80 \%+ \\
\text { Additive } 2.0 \mathrm{ml}\end{array}$ & PB20 Additive $2.0 \mathrm{ml}$ \\
\hline 9 & Palm biodiesel 30\% + Diesel $70 \%$ & PB30 \\
\hline 10 & $\begin{array}{l}\text { Palm biodiesel } 30 \%+\text { Diesel } 70 \%+ \\
\text { Additive } 0.8 \mathrm{ml}\end{array}$ & PB30 Additive $0.8 \mathrm{ml}$ \\
\hline 11 & $\begin{array}{l}\text { Palm biodiesel } 30 \%+\text { Diesel } 70 \%+ \\
\text { Additive } 2.0 \mathrm{ml}\end{array}$ & PB30 Additive $2.0 \mathrm{ml}$ \\
\hline
\end{tabular}

\section{Experimental Setup and Method for Testing the Engine}

A schematic diagram of the experimental setup for the engine test is shown in Figure 1. The engine test was conducted on a single-cylinder direct injection compression ignition engine coupled with an Eddy current dynamometer.

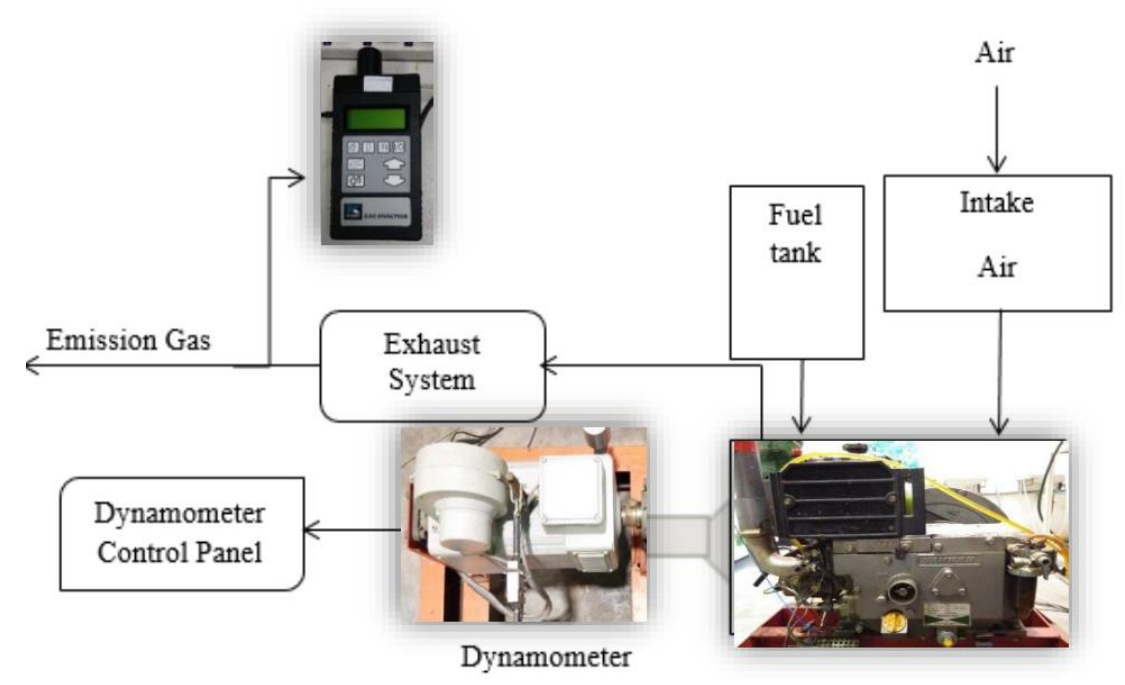

Figure 1. Schematic diagram of the experimental setup.

The specifications of the Yanmar TF90 engine and the dynamometer are shown in Tables 2 and 3, respectively. A BOSCH and a KANE gas analyser were used to analyse 
the emissions from the engine. The BOSCH gas analyser was used to detect the smoke opacity percentage, while the KANE gas analyser for the detection of $\mathrm{NO}_{\mathrm{x}}, \mathrm{CO}$ and $\mathrm{CO}_{2}$ emission.

Table 2. Engine specifications from Yanmar Diesel Engine Co. Ltd.

\begin{tabular}{lc}
\hline Details & Specification \\
\hline Model & YANMAR TF90 \\
Number of cylinders & 1 \\
Total volume (litres) & 0.493 \\
Compression ratio & 10.5 \\
Horsepower (kW) & 8.5 \\
Max. torque (Nm/RPM) & $3.4 / 1600$ \\
Capacity of cooling system (liter) & 8.9 \\
Max. rated power, RPM (kW) & $2400(8.5)$ \\
\hline
\end{tabular}

Table 3. Dynamometer specifications.

\begin{tabular}{lc}
\hline Details & Specification \\
\hline Model & MGFQU-100-22 \\
Max. power $(\mathrm{kW})$ & 12.5 \\
Max. rotating speed (RPM) & 3350 \\
Total weight & $65 \mathrm{~kg}$ \\
Inertia & $\mathrm{J}=0.0237 \mathrm{kgm}^{2}$ \\
\hline
\end{tabular}

The engine was tested with a load of $3 \mathrm{~kW}$ and at various speeds that had ranged from 1000 RPM to 2000 RPM. The experiment had started off with the use of a commercial diesel fuel in the initial investigation of the engine's performance and emissions. The performance and emission data from the diesel fuel were then used in the comparison of different blended fuels types. The same procedure was repeated for each blended fuel by maintaining the same operating conditions, namely a load of $3 \mathrm{~kW}$ and various speeds that had ranged from 1000 RPM to 2000 RPM. This experiment had utilised two types of fuel (diesel and palm biodiesel) and one type of additive.

\section{RESULTS AND DISCUSSION}

\section{Analysis of the Blended Fuel Properties}

Figures 2(a), 2(b) and 2(c) show the respective densities, kinematic viscosities and calorific values of the biodiesels which had been blended with the additive and those without additive, which had complied with the ASTM D7467 standard. The density for all the blended fuels was between the range of $825 \mathrm{~km} / \mathrm{m}^{3}$ to $838.5 \mathrm{~kg} / \mathrm{m}^{3}$, where it was observed that the fuel density had increased with the increased percentages of the additive and biodiesel of the mixture. All the blended fuels had complied with the ASTM D7467 standard and it can be seen that the highest kinematic viscosity of $4.1 \mathrm{~mm}^{2} / \mathrm{s}$ was attained by PB30 Additive $2.0 \mathrm{ml}$. While the highest calorific value of $45.286 \mathrm{MJ} / \mathrm{kg}$ PB10 was shown in Additive $0.8 \mathrm{ml}$ biodiesel, PB20 on the other hand, had displayed the lowest calorific value of $44.03 \mathrm{MJ} / \mathrm{kg}$. 


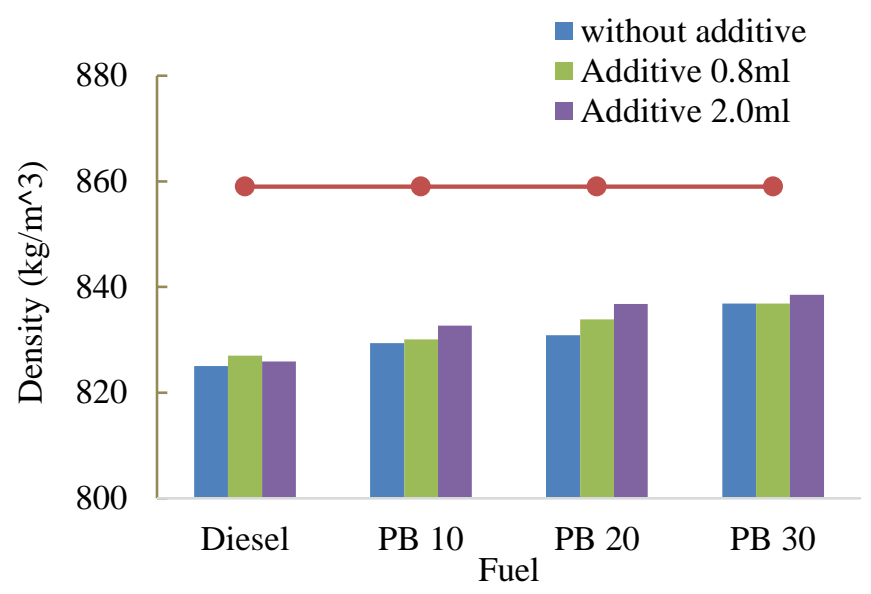

(a)

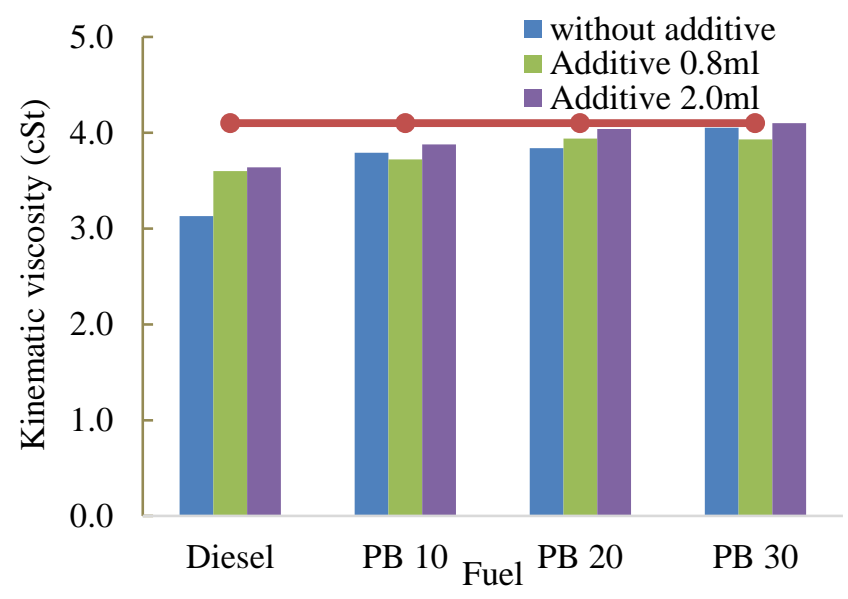

(b)

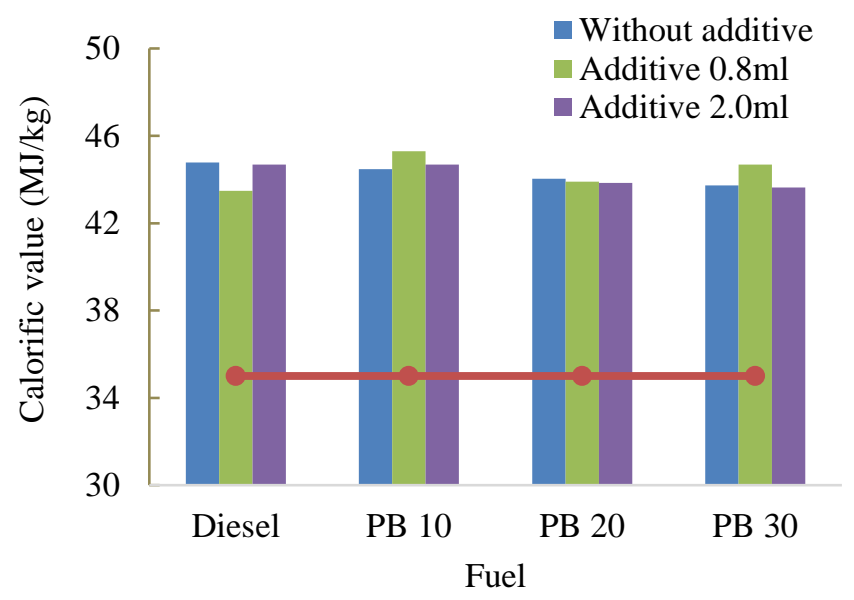

(c)

Figure 2. Blended fuel (a) density, (b) kinematic viscosity and; (c) calorific value.

\section{Engine Performance}

Figure 3 shows the graph of braking power plotted against the speed of the ideal biodiesel blend and diesel. With a load of $3 \mathrm{~kW}$ applied to the Yanmar TF90 diesel engine, the 
maximum brake power of diesel, PB10, PB10 Additive $0.8 \mathrm{ml}$ and PB 10 Additive $2.0 \mathrm{ml}$ at $2000 \mathrm{RPM}$ are shown as $1.783 \mathrm{~kW}, 1.777 \mathrm{~kW}, 1.793 \mathrm{~kW}$ and $1.783 \mathrm{~kW}$, respectively. The braking power of PB10 Additive $0.8 \mathrm{ml}$ is the highest when compared to diesel, PB10 and PB10 Additive $2.0 \mathrm{ml}$ since the biodiesel blend has the highest calorific value compared to the diesel and a higher content of oxygen with a lower kinematic viscosity and density among all of the blends.

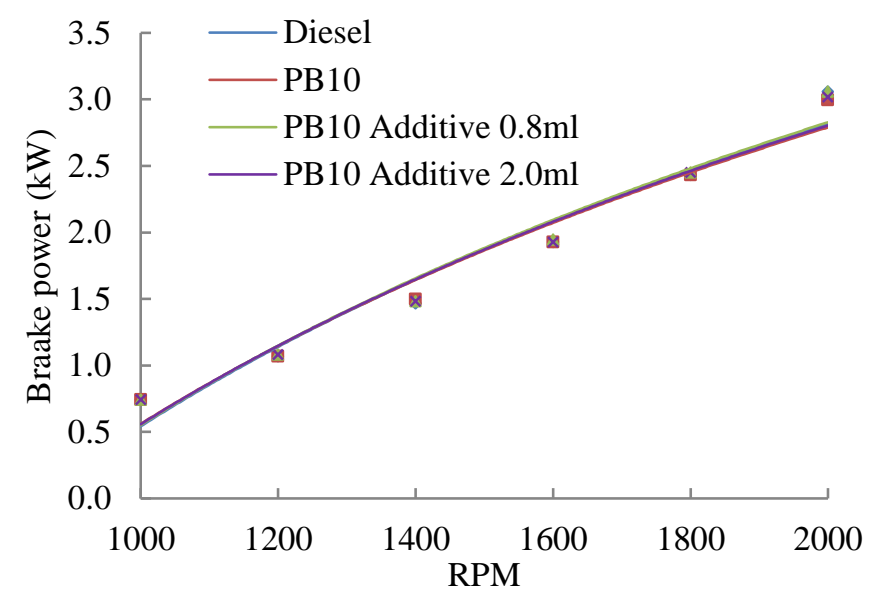

Figure 3. Graph of brake power against speed.

Figure 4(a) to 4(c) show the brake specific fuel consumption (BSFC) for the respective biodiesel blends and diesel fuel. While the lowest BSFCs obtained for biodiesel PB10, PB10 Additive $0.8 \mathrm{ml}$ and diesel Additive $2.0 \mathrm{ml}$ at $2000 \mathrm{RPM}$ are shown as $0.308 \mathrm{~kg} / \mathrm{kWh}, 0.305 \mathrm{~kg} / \mathrm{kWh}$ and $0.311 \mathrm{~kg} / \mathrm{kWh}$, respectively, the highest BSFCs obtained for the corresponding PB30, PB30 Additive $0.8 \mathrm{ml}$ and PB20 Additive $2.0 \mathrm{ml}$ at $1000 \mathrm{RPM}$ are $0.424 \mathrm{~kg} / \mathrm{kWh}, 0.443 \mathrm{~kg} / \mathrm{kWh}$ and $0.424 \mathrm{~kg} / \mathrm{kWh}$. The decrease in the BSFCs is due to the better physical and chemical properties of the biodiesel blends and additive for combustion at high speeds. In PB10 Additive $0.8 \mathrm{ml}$, the lower BSFC is caused by its higher calorific value, whilst the increase in the BSFCs for PB30, PB30 Additive $0.8 \mathrm{ml}$ and PB20 Additive $2.0 \mathrm{ml}$ shows a higher level of fuel consumption due to their lower calorific values and higher density levels. It is observed that PB10 experiences a decrease in the BSFC as compared to the diesel fuel. Hence, it can be concluded that PB10 Additive $0.8 \mathrm{ml}$ is the optimum blend for obtaining a higher power and torque output with lower BSFC.

The brake thermal efficiencies of the engines using diesel, biodiesel and additive blends are shown in Figures 5(a) to 5(c). The results indicate that the brake thermal efficiency for all the fuel blends had a similar trend with the diesel fuel. While the highest BTEs for PB10 (26.38\%), PB10 Additive $0.8 \mathrm{ml}$ (26.03\%) and PB10 Additive $2.0 \mathrm{ml}$ (25.95\%) is lower than diesel Additive $0.8 \mathrm{ml}$ (27.03\%), the diesel Additive 2.0ml on the other hand, displays the highest BTE due to its lower density, lower kinematic viscosity and higher calorific value compared to the blended biodiesel. The small amount of additive that was added to the diesel had produced a better BTE at s high speed. It can be seen that the PB10 Additive $0.8 \mathrm{ml}$ demonstrates a high trend at a lower speed compared to the diesel Additive $0.8 \mathrm{ml}$ due to its higher calorific value and kinematic viscosity, which is almost similar to that of the diesel Additive $0.8 \mathrm{ml}$. Overall, the higher percentage of biodiesel content reduces the BTE due to its weak combustion spray characteristics and the weak air-fuel ratio of the mixture. 


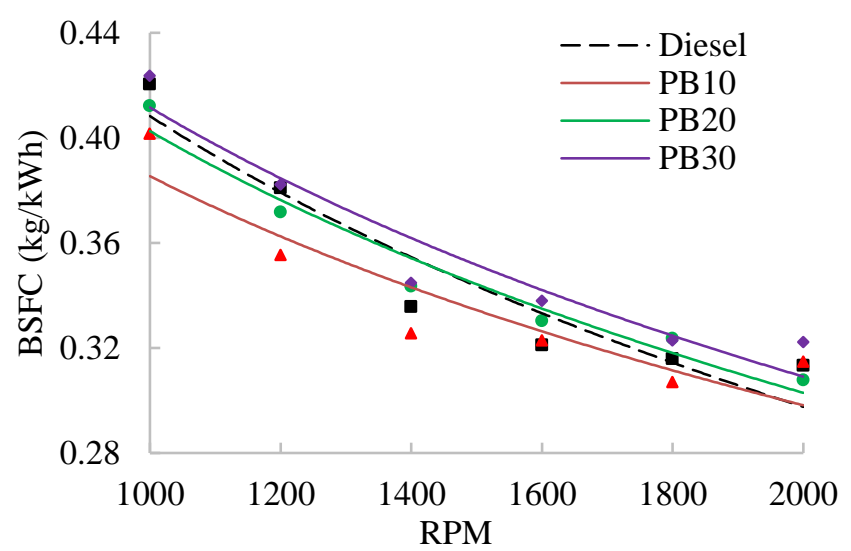

(a)

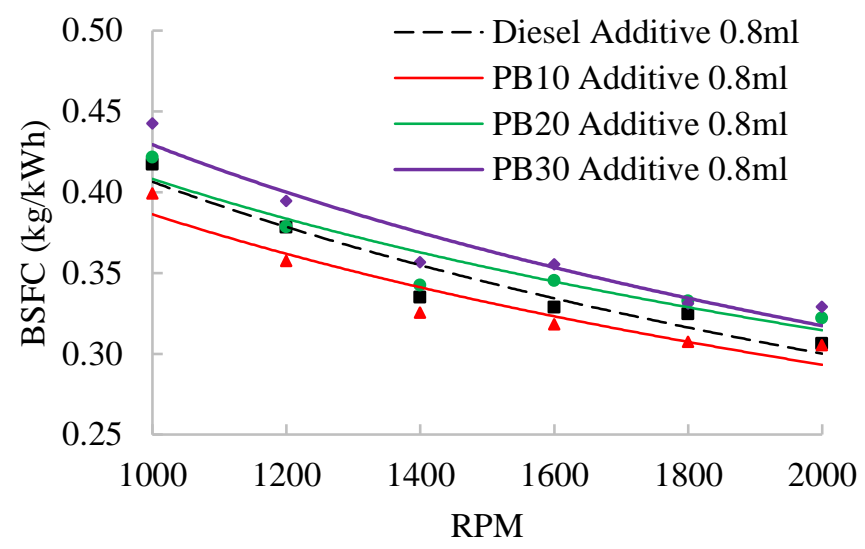

(b)

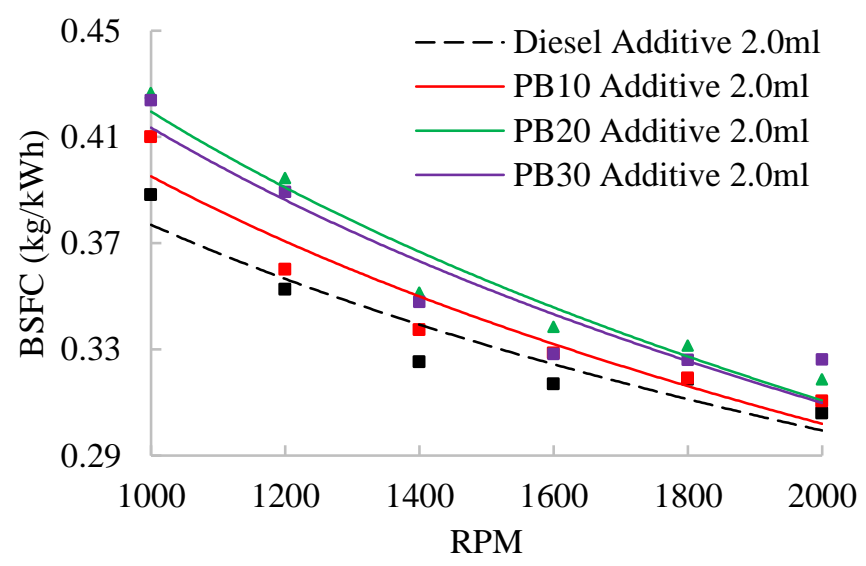

(c)

Figure 4. BSFC against Speed for (a) fuel, (b) fuel Additive $0.8 \mathrm{ml}$ and; (c) fuel Additive $2.0 \mathrm{ml}$. 


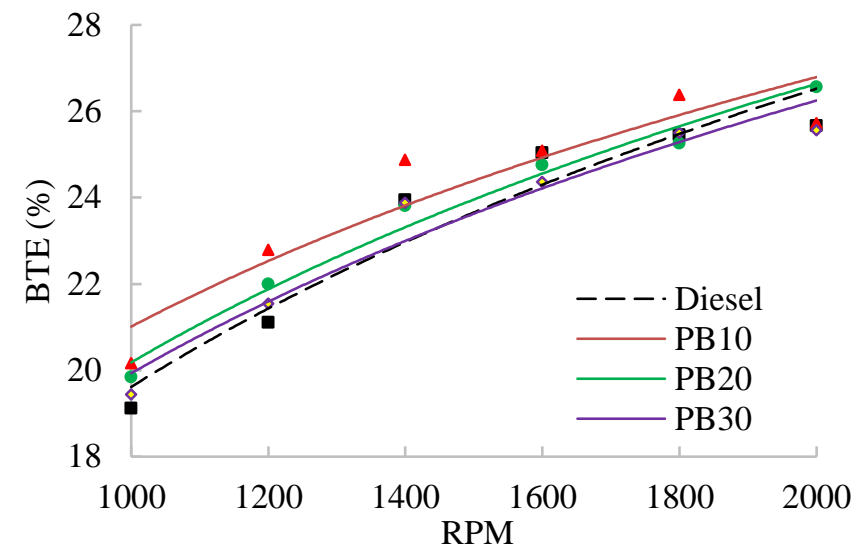

(a)

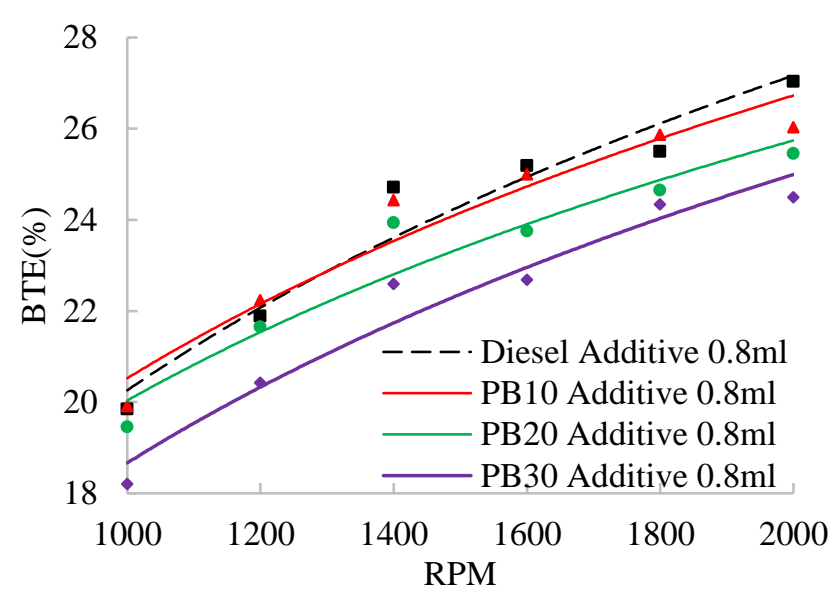

(b)

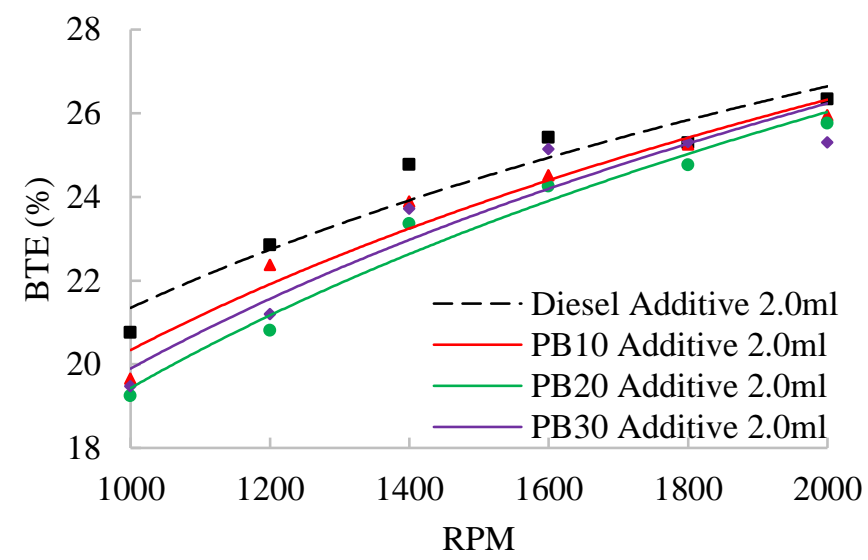

(c)

Figure 5. Brake thermal efficiency (BTE) against speed for (a) fuel, (b) fuel Additive $0.8 \mathrm{ml}$ and; (c) fuel Additive $2.0 \mathrm{ml}$. 


\section{Engine Emissions}

Nitrogen oxide is a colourless and odourless gas that is highly toxic. Figures 6(a) to 6(c) show the $\mathrm{NO}_{\mathrm{x}}$ emission of the respective diesel, biodiesel and the additive mixture. As seen from the graphs, the lowest $\mathrm{NO}_{\mathrm{x}}$ emissions for diesel, diesel Additive $0.8 \mathrm{ml}$ and diesel Additive $2.0 \mathrm{ml}$ at $1000 \mathrm{RPM}$ are shown as $71 \mathrm{ppm}, 82 \mathrm{ppm}$ and $75 \mathrm{ppm}$, respectively, while the highest $\mathrm{NO}_{\mathrm{x}}$ emissions for the corresponding PB10, PB10 Additive $0.8 \mathrm{ml}$ and PB10 Additive 2.0ml at $2000 \mathrm{RPM}$ are $381 \mathrm{ppm}, 367 \mathrm{ppm}$ and 309 ppm. The high brake thermal efficiency for the biodiesel fuels is also observed to have indirectly increased the levels of $\mathrm{NO}_{\mathrm{x}}$ emissions.

The biodiesel with and without additives were seen to have higher $\mathrm{NO}_{\mathrm{x}}$ emission than the diesel fuels due to their higher oxygen contents. A research from Fattah et al. (2014) had stated that the increase of $\mathrm{NO}_{\mathrm{x}}$ emission was due to higher combustion temperatures, long combustion period and high oxygen concentration level in the biodiesel. Moreover, the better completion of combustion produced by the biodiesel fuel could also enhance the formation of $\mathrm{NO}_{\mathrm{x}}$ emissions.

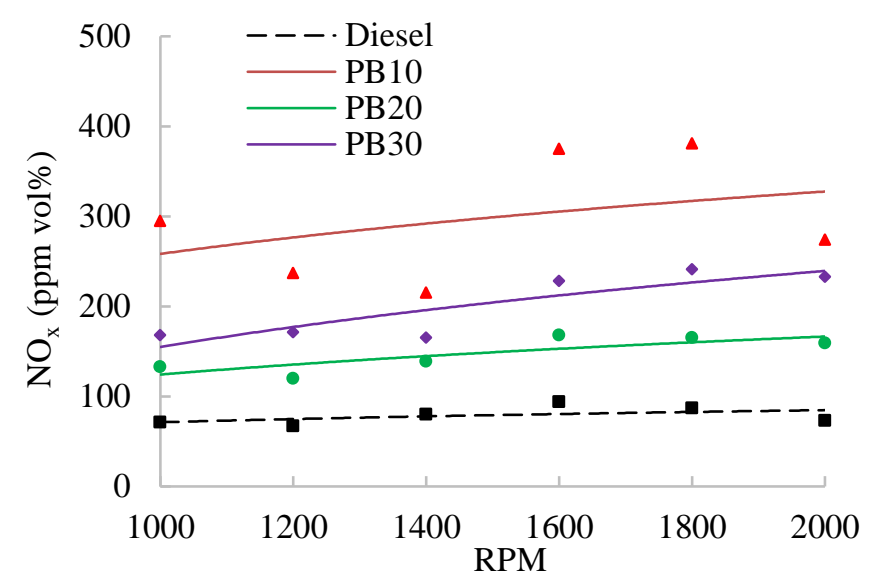

(a)

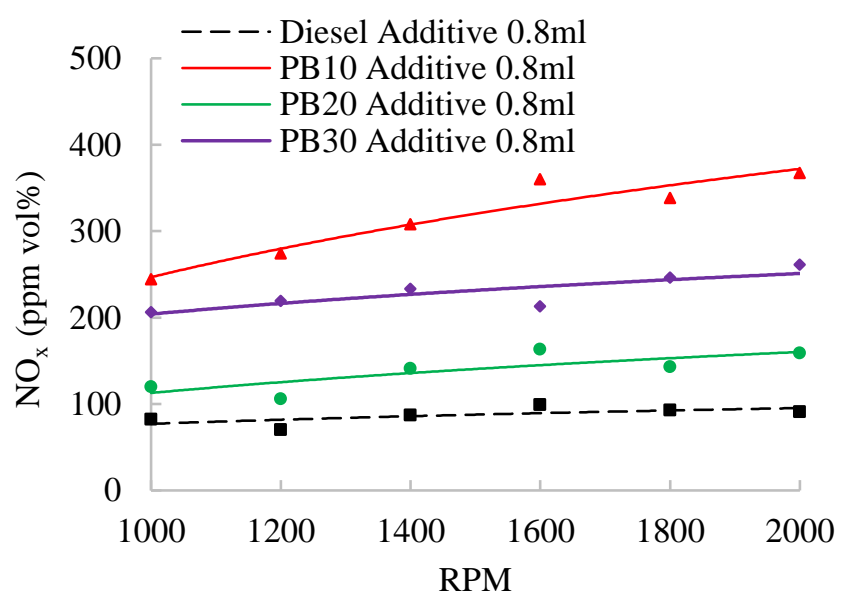

(b) 


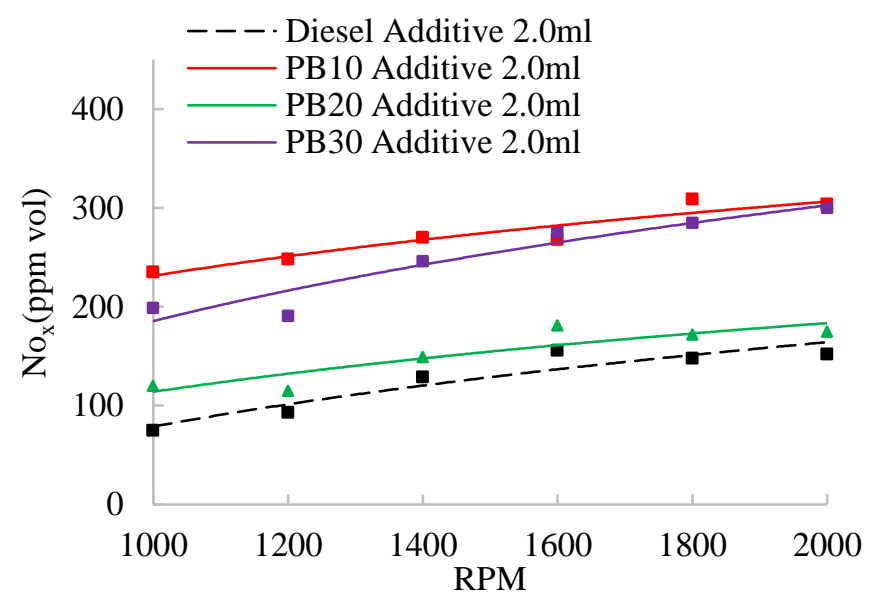

(c)

Figure 6. $\mathrm{NO}_{\mathrm{x}}$ emissions against speed for (a) fuel, (b) fuel with Additive $0.8 \mathrm{ml}$ and; (c) fuel with Additive $2.0 \mathrm{ml}$.

Figures 7(a) to 7(c) show the emission of $\mathrm{CO}_{2}$ by different types of fuel mixtures against the rotational speed of the engine. The biodiesel fuels of PB30, PB10 Additive $0.8 \mathrm{ml}$ and PB30 Additive $2.0 \mathrm{ml}$ have the highest $\mathrm{CO}_{2}$ emissions of $7.3 \%, 6.5 \%$ and $6.8 \%$, respectively, while the lowest $\mathrm{CO}_{2}$ emissions are from the corresponding PB20, diesel Additive $0.8 \mathrm{ml}$ and PB10 Additive $2.0 \mathrm{ml}$ at $4.6 \%, 3.9 \%$ and $3.9 \%$, where the $\mathrm{CO}_{2}$ emission is observed to be directly proportional to the increase of the engine speed. The higher $\mathrm{CO}_{2}$ emission from the biodiesel could be due to the inaccurate values displayed by the gas analyser.

The emission of $\mathrm{CO}_{2}$ is higher for biodiesel than diesel since the complete combustion had converted the $\mathrm{CO}$ to $\mathrm{CO}_{2}$. Theoretically, since biodiesel contains oxygen atoms and has a lower carbon to hydrogen ratio than the diesel, therefore, the emission of $\mathrm{CO}_{2}$ can be lower than those of the diesel.

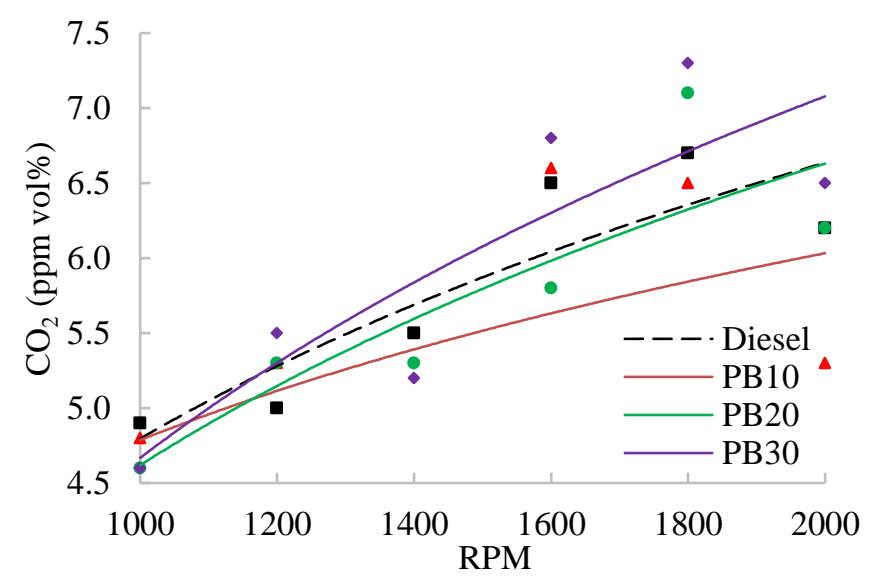

(a) 


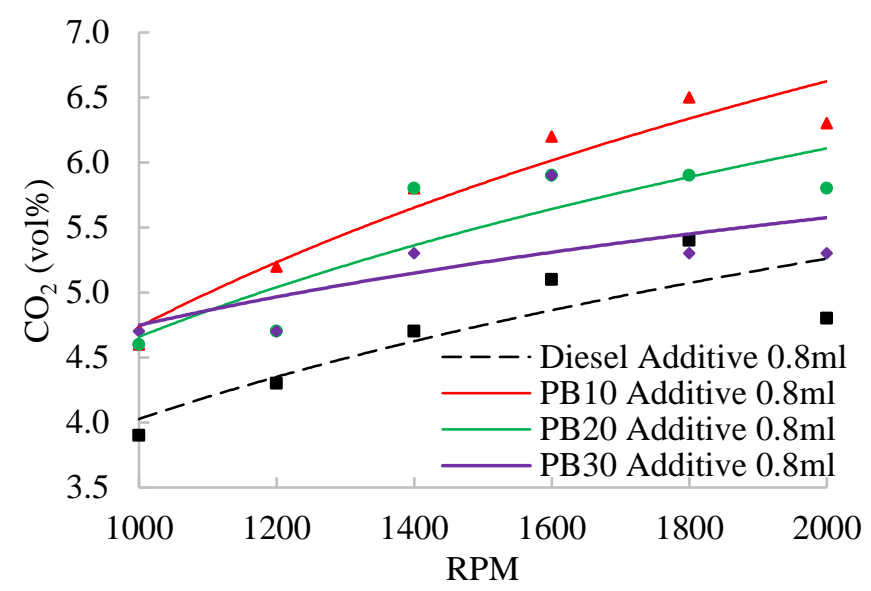

(b)

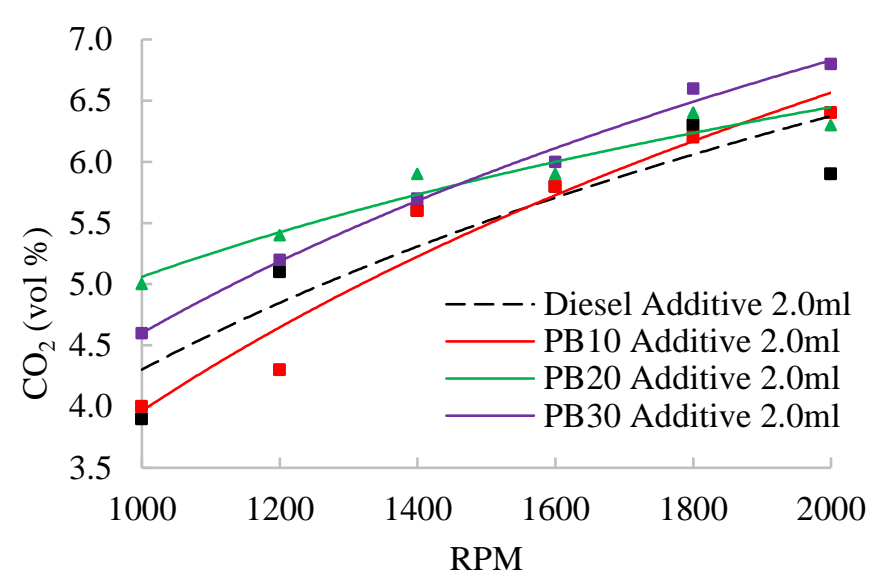

(c)

Figure 7. $\mathrm{CO}_{2}$ emission against speed for (a) fuel, (b) fuel Additive $0.8 \mathrm{ml}$ and; (c) fuel Additive $2.0 \mathrm{ml}$

Figure 8 shows the results of the average smoke opacity of the diesel and biodiesel fuel blends. It is observed that all the blends with and without additives had demonstrated lower smoke opacities than the diesel fuel loaded with and without additives. The lowest average smoke opacities are seen in the respective biodiesels of PB30, PB30 Additive $0.8 \mathrm{ml}$ and PB30 Additive $2.0 \mathrm{ml}$ at $3.72 \%, 3.97 \%$ and $3.15 \%$, while the highest smoke opacities can be observed in diesel, diesel Additive $0.8 \mathrm{ml}$ and diesel Additive $2.0 \mathrm{ml}$ at $6.7 \%, 4.38 \%$ and $6.33 \%$, respectively. The higher smoke opacity of diesel with or without additive is due to the incomplete combustion of the hydrocarbons and particulate carbon in the fuel.

From the results of this study, the high oxygen level in the biodiesel fuel not only has the ability to reduce smoke opacity but can also result in a more comprehensive combustion process than that of the diesel. Apart from that, the low carbon content in the biodiesel is also one of the factors that can cause the reduction of the smoke opacity level. 


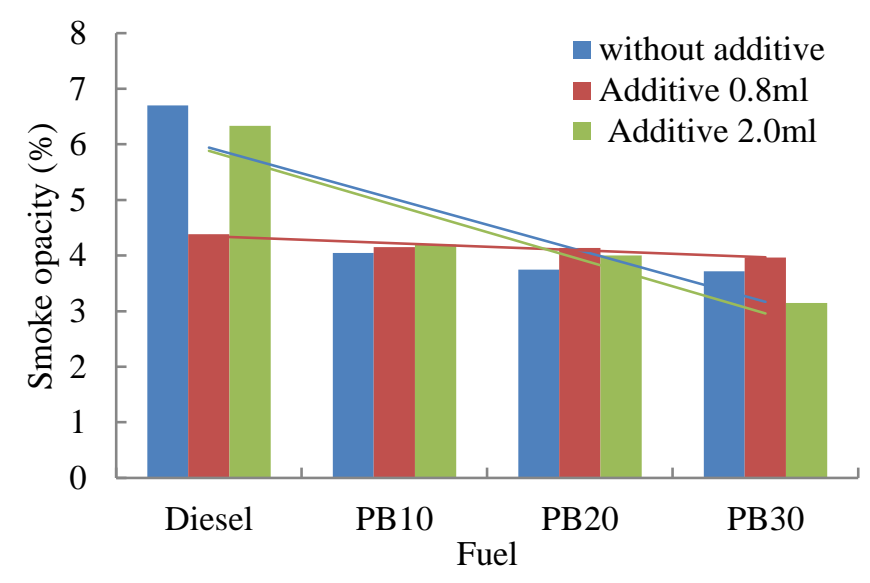

Figure 8. Average smoke opacity for different types of fuels with different additive percentages.

\section{CONCLUSION}

The engine performance and emission of diesel-biodiesel blends with additives were investigated using different blend compositions. In order to identify the engine performance, the density, viscosity and calorific values had been experimentally identified. The results of this study can be summarized as below:

i. The biodiesel and diesel fuels blended with and without additives fulfill the ASTM D6751 and EN14214 standards in terms of the density, kinematic viscosity and calorific values.

ii. The biodiesel BP10 Additive $0.8 \mathrm{ml}$ produces the best engine performance with the highest braking power. While the presence of biodiesel can slightly reduce the brake thermal efficiency (BTE), the lower concentration of the biodiesel-diesel blend leads to a reduction of the BSFC. The presence of additives and biodiesel in the diesel indicates PB10 to exhibit the best engine performance.

iii. The presence of biodiesel and additives not only increases the $\mathrm{CO}_{2}$ emission, but also leads to a reduction of smoke opacity from the combustion. However, the high oxygen contents in biodiesel and additives, produces a higher $\mathrm{NO}_{\mathrm{x}}$ emission compared to diesel.

iv. Since PB10 with $0.8 \mathrm{ml}$ of additives demonstrates the best engine performance with the most effective carbon emission reduction, this biodiesel blend is therefore regarded as the best and the most effective alternative fuel in diesel engine.

\section{ACKNOWLEDGEMENT}

The authors would like to thank the Ministry of Education Malaysia for supporting this research with grant no. FRGS/1/2017/TK07/UKM/02/1. The author would also like to thank Mr Azmi Abas from DHP LUBE Sdn. Bhd. for providing the additives.

\section{REFERENCES}

[1] Greenfield M. Year-on-year Growth in Global Passenger Car Production from 2006 to 2017. Statista. Retrieved from https://www.statista.com/statistics/ 262747/worldwide-automobile-production-since-2000/; 24 June, 2018. 
[2] Taib NM, Mansor MRA, Mahmood WMFW, et al. Simulation Study of Combustion Characteristics of Diesel- Ethanol-Palm Oil Methyl Ester Blends in Diesel Engine. Journal of Advanced Research in Fluid Mechanics and Thermal Sciences. 2018; 44: 149-156.

[3] Shafie SM, Mahlia TMI, Masjuki HH, et al. Current energy usage and sustainable energy in Malaysia: A review. Renewable and Sustainable Energy Reviews 2011; 15: 4370-4377.

[4] Bhaskar K, Sendivelan S, Muthu V, et al. Performance and emission characteristics of compression ignition engine using methyl ester blends of jatropha and fish oil. Journal of Mechanical Engineering and Sciences 2016; 10: 1994-2007.

[5] Aurélio M, Lagnier B, Ferreira G, et al. Comparative study of NOx emissions of biodiesel-diesel blends from soybean, palm and waste frying oils using methyl and ethyl transesterification routes. 2017; 194: 144-156.

[6] Geng P, Cao E, Tan Q, et al. Effects of alternative fuels on the combustion characteristics and emission products from diesel engines: A review. Renewable and Sustainable Energy Reviews 2016; 71: 523-534.

[7] Gulzar M, Masjuki HH, Kalam MA, et al. Oil filter modification for biodieselfueled engine: A pathway to lubricant sustainability and exhaust emissions reduction. Energy Conversion and Management 2015; 91: 168-175.

[8] Alptekin E, Canakci M. Determination of the density and the viscosities of biodiesel-diesel fuel blends. Renewable Energy 2008; 33: 2623-2630.

[9] Jayed MH, Masjuki HH, Kalam MA, et al. Prospects of dedicated biodiesel engine vehicles in Malaysia and Indonesia. Renewable and Sustainable Energy Reviews 2011; 15: 220-235.

[10] Taib NM, Mansor MRA, Mahmood WMFW, et al. Investigation of diesel-ethanol blended fuel properties with palm methyl ester as co-solvent and blends enhancer. MATEC Web of Conferences; 90. Epub ahead of print 2016.

[11] Monirul IM, Masjuki HH, Kalam MA, et al. assessment of performance, emission and combustion characteristics of palm, jatropha and calophyllum inophyllum biodiesel blends. Fuel 2016; 181: 985-995.

[12] Paul G, Datta A, Mandal BK. An experimental and numerical investigation of the performance, combustion and emission characteristics of a diesel engine fueled with jatropha biodiesel. Energy Procedia 2014; 54: 455-467.

[13] Taib NM, Zainuddin MS, Mansor MRA, et al. Performance and Emission Opacity of Canola and Soybean Biodiesel Fuel in a Diesel Engine. JOurnal of Mechanical Engineering and Sciences 2018; 12: 3689-3699.

[14] Palash SM, Masjuki HH, Kalam MA, et al. State of the art of NOx mitigation technologies and their effect on the performance and emission characteristics of biodiesel-fueled Compression Ignition engines. Energy Conversion and Management 2013; 76: 400-420.

[15] Ong HC, Masjuki HH, Mahlia TMI, et al. Engine performance and emissions using Jatropha curcas, Ceiba pentandra and Calophyllum inophyllum biodiesel in a CI diesel engine. Energy 2014; 69: 427-445.

[16] Habibullah M, Masjuki $\mathrm{HH}$, Kalam MA, et al. Biodiesel production and performance evaluation of coconut, palm and their combined blend with diesel in a single-cylinder diesel engine. Energy Conversion and Management 2014; 87: 250-257.

[17] Ali OM, Mamat R, Abdullah NR, et al. Analysis of blended fuel properties and engine performance with palm biodiesel-diesel blended fuel. Renewable Energy 
2015; 86: 59-67.

[18] Ozsezen AN, Canakci M. Determination of performance and combustion characteristics of a diesel engine fueled with canola and waste palm oil methyl esters. Energy Conversion and Management 2011; 52: 108-116.

[19] Khalid A, Tajuddin ASA, Jaat N, et al. Performance and emissions of diesel engine fuelled with preheated biodiesel fuel derived from crude palm, jatropha, and waste cooking oils. International Journal of Automotive and Mechanical Engineering 2017; 14: 4273-4284.

[20] Sanli H, Canakci M, Alptekin E, et al. Effects of waste frying oil based methyl and ethyl ester biodiesel fuels on the performance, combustion and emission characteristics of a di diesel engine. Fuel 2015; 159: 179-187.

[21] Sharon H, Karuppasamy K, Soban Kumar DR, et al. A test on DI diesel engine fueled with methyl esters of used palm oil. Renewable Energy 2012; 47: 160-166.

[22] Elango T, Senthilkumar T. Combustion and emission characteristics of a diesel engine fuelled with jatropha and diesel oil blends. Thermal Science 2011; 15: 1205-1214. 